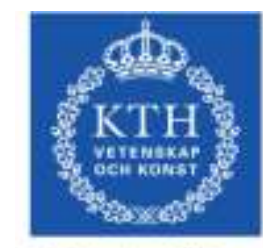

KTH Land and Water Retources Enginesring

\title{
LESSONS FROM PLACHIMADA FOR WATER LAW: WHO SHOULD OWN THE GROUNDWATER
}

\author{
Mahesh Menon
}

May 2013 
(C) Mahesh Menon 2013

Degree Project for the masters program in Civil Engineering and Urban Management Done in association with the Water Management Research group

Department of Land and Water Resources Engineering

Royal Institute of Technology (KTH)

SE-100 44 STOCKHOLM, Sweden

Reference should be written as: Menon, M. (2013) "Lessons from Plachimada for Water Law: Who should Own the Groundwater?” TRITA-LWR Degree Project 13:44 46 p. 


\section{SUMMARY ( SWEDISH)}

I juni 200 hade Hindusthan Coca-Cola Ltd (det indiska dotterbolaget till Coca-Cola) satt upp en fabrik i Plachimada, en lite by i delstaten Kerala. Bolaget beräknas kunna ha utvunnit mellan $500-1500$ tusen liter grundvatten per dag. Som resultat av denna massiva exploatering under kort tidsperiod av började efter sex månader många privata och gemensamma brunnar i byn att torka upp. Grundvattennivån sjönk från $45 \mathrm{~m}$ till $150 \mathrm{~m}$ och ca 260 grävda brunnar torrlades på mindre än tre år.

Responsen från de drabbade människorna var från början att söka politiska lösningar genom agitation och mobilisering. Gradvis kopplades dessa protester till rättsliga åtgärder. Men enligt en koloniallag från 1882 är rätten till grundvatten knuten till ägande av marken, vilket medförde att bolaget fick rätt att fortsätta utnyttja grundvattnet utan begränsningar på platsen och utan att behöva visa hänsyn till vattenrättigheter för övriga intressenter som är beroende av samma vattenresurs.

Med ett juridisk system som Indien har riskerar fall som Plachimada att upprepa sig på andra håll i Indien. För att undvika detta är en omarbetning av de lagverk som styr grundvattennyttjandet nödvändigt. Erfarenheterna av statliga ingripanden i Plachimada och andra liknande situationer lämnar mycket övrigt att önska. Rapporten argumenterar för att den rättsliga ramen över ägandet av grundvatten måste omarbetas till förmån för det lokala samhället som främst är beroende av resursen för både dricksvatten och jordbruket. I ett land med stora sociala orättvisor är de fattigas tillgång till grundvatten en rättighet som måste prioriteras före stora bolagskoncerners behov.

Nyckelord: Grundvatten, ägande, Indien, Plachimada. 


\section{SUMMARY IN ENGLISH}

In June 2010, the Hindusthan Coca-Cola Ltd. (The Indian Subsidiary of Coa-Cola) had set up a factory in Plachimada, a village in the State of Kerala in India. The Company is estimated to have extracted $500-1.5$ million litres of groundwater per day. As a result of this massive extraction in a short period of time, in about 6 months many private and public wells in the village started to go dry. Ground water levels dropped from 45 meters to 150 meters and about 260 dug wells were drained in less than three years.

Initirally, the affected people responded to this by seeking political solutions by way of agitations and mobilization and gradually coupled this with legal action. However, according to a law enacted in 1882, the right ower groundwater associated with ownership over a parcel of land. This law thus allowed the company to extract groundwater without any restrictions on the location or the need to show respect fr the water rights of others who are dependant on the same resource.

This legal environment creates the risk of incidents such as plachimada repeating elsewhere in India. To avoid this, a revision of the statutory framework governing groundwater is neccessary. Experience shows us that state intervention in such cases leaves much to be desired. This report, hence argues that the legal framework of ownership of groundwater needs to be recast in favour of the local community that is primarily dependant on the resource for both drinking and agriculture. In a country with great social injustices and poor access to water, the needs of person dependant on groundwater for drinking water and livlihood needs must be prioratized over the demands for large withdrawals.

Keywords: Groundwater, ownership, India, Plachimada. 


\section{ACKNOWLEDgements}

Firstly, I thank Prof. Dr. Ramesh for guiding me in writing this Dissertation - despite his initial reservations with my hypothesis, he challenged me to take up this topic and complete writing this thesis. For his wonderful guidance I owe this and much more.

Acknowledgements are also due to Dr. Nandita Singh and Dr. Jan-Erik Gustafsson who went through my drafts at all stages and offered valuable suggestions - both for the content and the writing.

I also wish to thank the Swedish International Development Cooperation Agency \& Govt. of Sweden for awarding me the Linnaeus Palme Scholarship which enabled my stay and research at KTH, Stockholm, Sweden.

I also wish to specially thank Dr. Nandita Singh \& Family who made my stay in Sweden a most memorable one - for a moment it never felt that I was away from my home.

Finally, I wish to thank my Parents, all my Teachers \& Friends who made it possible for me to cross this milestone.

Mahesh Menon

May 27, 2013. 


\section{TABle of Contents}

Summary (Swedish)

Table of Contents

Abstract

Introduction- The story of Plachimada

Plachimadas in the Making

Problem Background

Aim of study

Methodology

Results

The common law and regulation of groundwater 7

The English rule \& American Rules

The Public Trust Approach to groundwater

The Common Law in India and attempts at reform 13

The Regulation Of Groundwater: International Approaches 16

$\begin{array}{ll}\text { The Lessons from international experience } & 22\end{array}$

Reconceptualising The Groundwater Law For India $\quad 22$

The case for decentralization $\quad 22$

Strategies for India 24

Discussion and conclusion $\quad 28$

$\begin{array}{lr}\text { References } & \mathbf{3 0}\end{array}$ 


\section{Abstract}

In early 2000s, a small village in the Southern part of India - Plachimada, gained global attention for its willingness to take on a global multinational - the Coca Cola. The Coca- Cola soft drink manufacturing plant extracted millions of gallons of water every day - depleting the groundwater resources of the entire village. This prolonged extraction left decade old wells dry and its water unsuitable for drinking. Faced with this challenge, the villagers launched a marathon struggle demanding that the company be shut down. After years of protests and the global attention that it gathered, the company was forced to finally shut down its plant. However, the damage was already done - the groundwater sources had depleted almost beyond any repair.

In the background of this incident, this thesis looks at the legal framework concerning groundwater in India - which at present conceptualizes it to be purely private property. It needs to be remembered that Plachimada is no stand alone story: indeed it has the capacity to reproduce itself elsewhere and evidence is accumulating to show that smaller versions of the story are already in the making. Groundwater sources in India are fast depleting and projections indicate that it might exhaust within less than two decades in some parts of the country. In a country with large inequities of access, power, capacity and capability, such a phenomenon can leave the less empowered and the poor denied access to groundwater.

At once we may fall for the rhetoric of state ownership and management of groundwater. However, past experience, particularly from surface water management has shown us that equity, access or decisions that serve the interests of the weak are not always made - the State has its agenda of creating, reinforcing and recreating its power and control over natural resources.

This thesis, hence, argues that groundwater needs to be reconceptualised as belonging to the community and is to be managed by the community. The paper explores the legal options available before us at present to make such a formulation and further argues for a more constructive and engaging role for the Panchayat system, the constitutional envisagement for decentralization of governance, in the ownership and management of groundwater.

\section{Key words: groundwater, ownership, India, Plachimada}

\section{Introduction- The Story of Plachimada}

The multinational soft drink giant Coca-Cola (hereinafter "Coke") has had a chartered history in India. In the late 1970s, the company was forced to stop operations in India after the government found that it had violated the foreign investment laws of India (Kux, 1993). For a long time since then Coke stayed out of India. It was in 1992 that after India liberalised and opened its economy that Coke came back to India. Driven by cheap cost of production and a market hungry for new products, Coke was one of the earliest multinationals to enter India. (Aiyer, 2007). In the decade that followed, Coke bought out more than twenty smaller Indian bottling companies and established itself firmly in the market. To cater to the growing demand for soft drinks in Indian markets, soon it had to establish numerous bottling plants all over India. On the heels of this momentum, in 1999 the village of Plachimada, in the South Indian State of Kerala issued a license to Coke to build and operate a soft drink manufacturing facility within the village (hereinafter "the Company") (NUS, 2004). After having conducted satellite imagery surveillance, Coke had picked the spot as it was located between two large groundwater reservoirs (Cockburn, 2005). Perhaps, little was then 
thought of how this would be an event that would make sea changes in the lives of those villagers.

Plachimada is situated in the Palakkad district of Kerala, which is an important agricultural region for the whole State and is popularly known as one of the 'rice bowls of Kerala'. The region hence required large quantities of water for agricultural purposes and this need was primarily met through groundwater and canal irrigation. The villagers of Plachimada were predominantly landless, illiterate agricultural labourers and belonged to the Scheduled Castes or Scheduled Tribes (Bijoy, 2006). It was in this terrain where people depended on agriculture for livelihood and of socio- economic backwardness that an industrial unit, which consumed unusually large quantities of water, began its operation in the year 2000.

The plant was championed by the State Government as an example of the foreign investment it could attract. The plant had cost close to 25 million U.S. Dollars and had a maximum operating capacity of 1,500,000 liters per day (HPC, 2010). The villagers were also initially happy with the factory - it employed nearly 150 permanent staff and about 250 labourers on contract (NUS, 2004). But veiled behind these rosy figures was a tragedy in the making: The Company was tapping the groundwater resources of the locality using six bore wells - each with a depth ranging between 250 to 300 meters and from two open wells. From these wells between $0.15-0.3$ million liters of water were extracted - every day (HPC, 2010). To produce a liter of soft drink, Coke extracted and used 3.8 liters of water (Kysar, 2005).

It did not take too long for the villagers to feel effects of such a massive scale extraction. In less than six months, the villagers started to complain that water levels in their wells were dropping dramatically with some of them running dry. It was also reported that water "turned brackish, milky white in colour and tasted bitter" (NUS, 2004). Some health issues also popped up - ranging from stomach upsets to rashes on the skin (Cockburn, 2005). The plant had also produced some quantities of sludge (which the Company gave away to the farmers for free describing it to be a fertilizer) which was later found to have dangerous levels of toxic contents (BBC, 2003). For more than a year since then this situation continued unabated. With little connection to the mainstream society or the apparatus of the State, the people of Plachimada endured these effects for a considerable length of time as complaints fell on deaf ears and legal avenues for their redress were beyond their access. On 12 May 2003, the District Medical Officer of the district announced that people are not to drink water from the wells next to the Company as the concentration of chlorides, dissolved solids and the hardness of the water was far beyond tolerable limits for human consumption, domestic use or even irrigation (Bijoy, 2006). Agriculture was also at the receiving end of this extraction. Earlier, a little patch of land in this region yielded up to 500 kilograms of paddy or 1500 coconuts. Even though both of these were water intensive crops, prior to the arrival of the company, the villagers had never faced water shortage. Within 3 years of the factory being established, the irrigation wells ran dry and agricultural production declined, in some places up to 100 percent (Sen, 2003; Hazards Centre, 2006). The receding of the water table and the dramatic decrease in the quality of water spread to a distance of more than a radius of 2 kilometres of the plant within the next 2 years (Bijoy, 2006). 
Fed up with neglect by the state and with a grievance beyond what they could bear, the local villagers began a peaceful protest on 22 April 2002. The Plachimada struggle was launched by the 'Coca-Cola Virudha Janakeeya Samara Samithy' (Anti Coca-Cola Peoples Struggle Committee) with a blockade by more than 1300 people who were mostly tribals. Their demand was that the plant must be shut down and that Coke be held fully responsible for the destruction of their habitat. Coke responded to this with a police complaint and for once the administration was quick to respond - by arresting and removing the protestors. Coke then approached the High Court of Kerala in 2002 demanding police protection for its functioning and a prayer that the picketing be dismantled. The Court concluded that the people had a right to protest peacefully and ordered the police to provide protection to both the plant and the protestors (Coca Cola Case, 2002). Initially, the protest received attention from the neither the mainstream political parties nor the media. However, gradually, the protest gained momentum and it assumed the proportions of a large scale movement with global attention (Bijoy, 2006; BBC, 2003; The Guardian, 2004).

Under pressure from the protestors, the media and the public, the Panchayat in 2003 decided to cancel the license to function granted to Coke. It was resolved by the Panchayat that:

"As the excessive exploitation of groundwater by the Coca-Cola Company in Plachimada is causing acute drinking water scarcity in Perumatty Panchayat and nearby places, it is resolved in public interest, not to renew the license of the said Company." (Coca Cola Case, 2003).

Pursuant to this resolution, a notice to show cause was issued to the company seeking its response to the proposed cancellation. The company responded that the allegations of groundwater depletion or other environmental problems owing to the working of the company were without any evidence and that the Panchayat had no powers to cancel the license. This reply was rejected by the Panchayat and a notice of cancellation of license was issued to the company on 15 May 2003 and Coke was ordered to stop production. In response to this, OP No 13513/2003 was filed by the Company before the High Court of Kerala with a prayer for quashing the aforesaid resolution. However, this petition was rejected by the High Court and Coke was asked to approach the appellate authority under the Kerala Panchayat Law. The Company then challenged this order before the Department of Local Self Government Institutions of the Government of Kerala (the appellate authority) which stayed the order of cancellation. The government had concluded that there was insufficient evidence to link the depletion of groundwater with the operation of the company and hence ordered the Panchayat to constitute of team of experts to study the situation and to investigate into the allegations. Till such time the study was completed, the company was allowed to continue functioning unhindered (Koonan, 2007). The Panchayat was quick to challenge this order before the High Court of Kerala. On the first instance, the High Court ruled in favour of the Panchayat. However, the Company appealed to a division bench of the same Court, which ruled in favour of the Company. It was held that the Company had a right to extract whatever quantity of water that it required and that the Panchayat could not obstruct the functioning of the company on the ground that it used excessive quantities of water. This conclusion was reached as the court found the Indian Easements Act to be grating the company ownership of the groundwater below the land it held. The Court further directed the Panchayat to grant the 
company a license to function. While complying with this order of the High Court, the Panchayat sought to impose some conditions, one of which was that the company could not extract any groundwater. The company once again challenged this before the High Court and it was ordered by the Court that no such restrictions could be placed on the Company (Coca Cola Case, 2005a). Both the State of Kerala and the Panchayat appealed against this decision before the Supreme Court where the appeal is still pending (Coca Cola Case, 2005b).

With the judiciary also turning down the hopes of the people, the villagers of Plachimada were forced to turn to the State Government for help. By this time the protest movement had strengthened and gained both national and international attention. The government could no longer afford to ignore the plight of the villagers of Plachimada. In the year 2004, the district of Palakkad, in which Plachimada is situated, had witnessed unprecedented drought and linking to this, on February 17, 2004, the Government of Kerala suspended all groundwater withdrawals by the factory for a period of four months (Rajeev, 2005). In the months that followed, a series of government investigations brought out evidence that the Company was releasing various kinds of toxic chemicals into the soil (Swamy, 2011). Following this, on August 10, 2005, the Kerala State Pollution Control Board (PCB) cancelled the Companies' license for operating its waste treatment facility. Under the Panchayat Raj Law of Kerala, to obtain a license from a Panchayat, the applicant must be in posession of all the necessary licenses and clearances from the Pollution Control Board. The Panchayat then used that decision of the PCB to deny license to the company after it had expired. Coca- Cola has ever since then not been able to reopen the factory at Plachimada for this reason.

But the people of Plachimada are yet to be compensated for their losses. Several people suffered from the release of toxic substances and many more because agriculture had come to a standstill. In 2011, the Legislature of Kerala enacted the Plachimada Coca-Cola Victims Relief and Compensation Claims Special Tribunal Bill, 2011 to create a tribunal that is to adjudicate claims award compensation to persons who were affected by the functioning of the Plant. A High Powered Committee of the Government that investigated the extent of damages caused by the Plant estimated it to be to the tune of 2160 million Indian Rupees. (HPC , 2010) The Committee arrived at this figure considering the losses caused to agriculture, health, and costs of providing water, loss of wages, opportunity losses and costs to clean up the pollution caused. However, this Bill requires the assent of the President of India before it can take effect as law and it is yet to receive his assent (Misra, 2013).

\section{Plachimadas in the Making}

At once it is inviting to consider Plachimada as a standalone incident. One cannot imagine every day extraction of unusually large quantities of water and consequently wells running dry. The truth is however quite far from this. The fact seems to be that Plachimadas are in the making, slowly and largely unnoticed, in different parts of the country:

At Kaladera, a small village in the arid State of Rajasthan where Coke has a plant, the wells have already gone dry (India Resource Centre, 2011). A governmental agency has issued a report stating that the operations of the plant had severely impacted groundwater levels and has lead to "ecological imbalance" in that area (The Hindu, 2004a). Here again the 
villagers been have protesting for years, demanding that the plant be shut down (The Hindu, 2004b).

The story is repeating itself at Mehdiganj a village close to Banares in Uttar Pradesh. After a Coke manufacturing plant was established in the village in 1998 the water table fell considerably. Here again the villagers who are dependent on agriculture face a potenital loss of livelihood due to lack of water for irrigation. When petitions to the machinery of the State evoked no response, the villagers started protesting, demanding that the factory be shut down (India Resource Centre, 2013).

Not too far from Plachimada, the villagers of Sivaganga in Tamil Nadu were also forced to take to streets after Sakthi Sugar Mills, a unit that produced bottled water for Coca-Cola was running the groundwater dry (Viswanathan, 2003) . Similarly, after protests by villagers that lasted for more than two years, the Ministry of Environment and Forests directed the Soft drink manufacturing unit of Pepsi at Madhurawada to stop using groundwater. However, by that time the water table had already fallen considerably (Business Line, 2006).

Resistance to a beverage bottling plant in the southern Tamil Nadu district of Tirunelveli intensified over the years as the villagers feared that a water intensive industry in their village that depends on groundwater for agriculture would affect their livelihoods. Not too far from there, since 2005, villagers of Gangaikodan in Tamil Nadu have been demanding that the Coke Plant in their village be shut down (Viswanathan, 2005).

To be fair it is not just the multinational companies that engage in this predatory practice. The home grown varieties are also banking on the groundwater resources to reap huge profits. The people of Mathur, a village in the Tiruvalluvar district in Tamil Nadu has been campaigning for the past 15 years against corporate extraction of groundwater. Private Companies have been extracting groundwater to supply the growing water demands of Chennai, a metropolitan city near the village (NUS, 2004). The bottling plant of Sri Saravana Mills at Khammam district of Andhra Pradesh extracts massive quantities of water and the villagers have been forced to the streets to mark their protest. The factory draws about 225,000 litres of water per day as a result of which the bore wells in certain areas of Sattupalli village (with a population of 25,000 ) are reported to have dried up (NUS, 2004).

The Indian market for bottled water is growing at a fast pace and most companies depend on groundwater as its raw material. Along with this more and more incidents of clandestine water mining are being reported in the news papers every day (India Today, 2012; Economic Times, 2012; Wyrwoll, 2012).

Even a cursory glance at these incidents reveals certain similarities in the way they unfold: The plants are located in villages which usually depend on groundwater for drinking water and irrigation; over years the water table falls due to over extraction, causing wells to run dry reducing the availability of water for irrigation or even drinking; the complaints to the machinery of the State evokes no response; and the people of the village are forced to come on street in protest. However, once the protests begin the machinery of the State work -not to find a solution to their grievance, but to curb them with iron fists (Shiva, 2005).

In India it is reported that more than $60 \%$ of the people depend on groundwater for their drinking water needs (CPCB, 2013). In Rural India this figure touches up to $90 \%$ (Hoering, 2008). Groundwater extraction 
has grown post 1950s, particularly for irrigation purposes. Coupled with this is a groundwater crisis in the making. Reports seem to indicate that large parts of India are increasingly becoming water stressed (CPCB, 2013).

How do we then reconcile competing claims to the use of groundwater, and most importantly, who should decide on these claims? Reading through the incidents that were described one also finds that when conflicts arise communities are forced to pitt themselves against the apparatus of State. With little or no support from the State, the people are driven to mass protest. Such a situation arises because water issues are local issues. It hurts only the deprived and drives action only from them -authorities, the citizens or even the civil society that lives far from such locations does not feel the threat of thirst unquenched.

In this terrain of limited groundwater, communities disconnected from the mainstream and little scope for the concern to be taken up by people beyond the geography of deprivation, an important question pops up who should be the owner of groundwater?

Indian law on groundwater is yet to wake up from a legislation of the Colonial Times. Enacted in the year 1882, when technology was limited and groundwater extraction was only in the form of open wells, The Indian Easements Act in effect rendered groundwater as private property. Any person who owns land can extract all the groundwater that he desires to do so, with no caps any whatsoever. The effect of this legal framework is twofold: firstly that that only those who own land have any rights over groundwater. Secondly, a landowner can extract all the groundwater that he wishes to -without any regard to the rights of even adjacent landowners and the community that depends on the resource.

In the present times, when technology to extract groundwater has grown and bore wells that are thousands of feet deep can be dug, the present legal framework fits the description "archaic". It is argued in this thesis that in view of the coming into force of the Constitution of India and the firm position of public trust within Indian law, groundwater is no longer an individual property right - but one that belongs to the State. However, the argument does not stop here: In view of the nature of groundwater dependence in India, particularly by the rural agricultural communities, it is posited that consistent with the constitutional aspirations for decentralisation, as reflected in the $73^{\text {rd }}$ and $74^{\text {th }}$ Amendments, groundwater must also be the property of the community - to be vested in the Panchayats. Being a natural resource on which the entire community has a stake on, it is argued that communities must own the resource and decisions on its appropriation must be made by communities and not left to entities and persons who have little to lose and much to gain from the utlilization of the resource.

\section{PROBLEM BACKGROUND}

India is one of the fastest growing economies in the world and multinational companies are seeking to take advantage of the expanding market for consumer goods. In line with this trend several multinational soft drink companies are setting up more bottling plants all over the country to cater to this growing demand. These bottling units use groundwater for its manufacturing purposes - in unduly huge quantities, depleting the resource and leaving a population dependant on it for drinking \& irrigation without access to water. 
The Indian law on groundwater favours this exploitative situation by making groundwater a part and parcel of ownership over land. A landowner may withdraw any quantity of groundwater that he wishes to, even if he injures his neighbor or the public in that process. In the light of the changing nature of groundwater use and a market oriented economy taking shape, there is a need to change the Indian legal approach to groundwater.

\section{Aim OF STUDY}

The general aim of the study is to make an analysis of the limitations and shortcomings of the current legal framewrok over groundwater law in India and to propose an alternative to the present framework.

The specific aim of the study is to determine the alternate framework of law that needs to be adopted. A change from ownership by individuals can either be to a state centered one or a decentralized one- where groundwater is placed in the ownership of the community that use and conserve it. The paper makes a comparison of both these frameworks and attempts to find a framework that fits the Indian conditions.

Towards this end, the legal framework on groundwater in India is first examined and its shortcomings are identified. The legal framework of other countries (of both the common law and civil law legal systems) across the globe is then analysed to identify the current global trends in the regulation and management of groundwater. The results from this analysis are then applied to the Indian context to suggest a groundwater legal framework that suits the Indian conditions at large.

\section{METHODOLOGY}

The question of ownership over groundwater is a doctrinal question in law and hence most of the research is a doctrinal one. The research is also a descriptive and an analytical one. By comparing legal frameworks of different countries over this issue and learning from them, the framewrok that best suits the Indian conditions is sought to be identified.

With very few academics works published on this issue, the introductory chapter and the problem background was built primarily from newspaper reports, reports from non-governmental organizations and a few governmental reports. The rest of the chapters are analysis of the law. The primary sources for this are Constitutions, legislations and decisions of courts. The secondary sources are reports of research organizations, reports of International Organizations, peer reviewed articles \& books. For the purpose of comparison, countries have been selected based on the following criteria: (i) They must follow the 'rule of law'; (ii) the concerned countries must have a legislation covering groundwater, preferably enacted in the last 20 years; and (iii) The size of the countries: both small and large countries are surveyed in order to ascertain the existence of differences in regulatory approaches.

\section{RESULTS}

\section{The common law and regulation of groundwater}

The "Common Law" is the term used to express the Anglo - Saxon Legal Systems. The Common Law evolved in England and was brought to India and America by Britain as they colonised the respective States. This chapter makes a study of the common law approach towards 
groundwater regulation and ownership. The first sectionis devoted towards examining the English Rule and a few other Common law doctrines that has been applied in the United States of America. Since the common law approach was found to be inadequate to respond to the challenges raised by rising population, industrialisation and increased water demands, another approach devised by Common law courts and legislatures alike is the Public trust approach. The Second section will make a critique of this approach to examine how far this approach solves the particular problems in India. The third section examines the application of the common law principles in India and more particularly, this section will also examine the reforms that Indian law has sought to make into the common law framework. It will be examined whether the proposed directions of these reforms are adequate to solve the problems particular to India.

\section{The English rule \& American Rules}

Prior to the arrival of the British, the Indian Legal system was one built primarily on custom. Groundwater use in India dated back to several centuries before the arrival of the British. Consistent with the long tradition of natural resource management under the indigenous legal systems, there were customary laws and practices regarding the use and management of groundwater too (Vani, 2002). Despite these practices and customs that were centuries old, the present legal framework on groundwater - which is a mix of custom and statute - is more or less a colonial inheritance. The current conceptions of groundwater rights in India are hence derived from a mix of the Common law of England and Statutes that are in line with these Laws. While the dominant thinking for a long time appeared to be that these laws have not been disturbed by the Constitution of India, it is argued in the last part of this section that the doctrine of Public Trust, which the Supreme Court of India has declared to be a part of Indian Public Law, has overridden these laws and has brought about a change in the groundwater ownership law. But before that argument is made, it is imperative that one explains the statutory framework on the law concerning groundwater.

As pointed out before, the Indian Statutory law is more or less a reflection of the position of the English Common law on groundwater. Of particular significance here is that in the history of water law, groundwater and surface water has been subjected to two completely different regimes. Surface water received much more legal attention and hence the legal developments surrounding it was along the lines of the notion of the rights of riparians, that is, the usufructuary rights which were subject to the control of the State. Principles that evolved under the common law addressed the different kinds of rights of persons who used surface water (Getzla, 2004).Groundwater, however, was dealt with under a different regime, as a part of an individual's right to enjoy property (Tarlock, Corbridge \& Getches,2002). This then meant that there was no State control available over sources like wells, tanks or tube wells which existed within private lands.

The approach of the common law was to consider groundwater as a part of the soil under which it existed - a chattel that was attached to land which had no separate possibility of ownership (Singh, 1991). An ancient maxim generally referred to in this context is cuis est solum, eius est usque ad coelum et ad inferos - to whomsoever the soil belongs he also owns it to the sky and down to the depths (Broom, 2010). According to this rule, no restrictions applied both above and underneath the land and all natural 
products emanating from the land belonged to the owner of the land. This then also translated in the context of groundwater to mean that the Common law permitted a land owner to extract any quantity of groundwater that he deemed fit. There was no rule that prohibited him from extraction, even if he damaged the resource or diminished his neighbor's wells (Rao, 1996). According to the common law, the situation is one of damnum sine injuria (damage without any legal injury) (Frazier's Case, 1861).

The Statutory Law of India codified this position and holds that an easement may be a restriction on the ownership or use of groundwater. Section 17 (d) of the Act is clear in that there could not be any prescriptive right in water, not passing through any defined channel (i.e. groundwater). The law concerning this position has evolved from the English decision in Acton v. Blundell, decided in 1843, which held that an easement right cannot be obtained over the percolating groundwater that flows through undefined channels. The specific question before the Court in that case was whether groundwater is governed by the same rule that applied to surface water. If the riparian -rights doctrine applied, there would be a natural right to flowing water, without any diminish of quantity or quality. The Court, however, decided otherwise. It was held that groundwater, unlike surface water:

"falls within that principle, which gives to the owner of the soil all that lies beneath his surface; that the land immediately below is his property, whether it is sold rock, or porous ground, or venous earth, or part soil, part water..The person who owns the surface may dig therein and apply all that is there found to his own purposes and his free will and pleasure" (Acton's Case, 1843)

Thus the landowner had unlimited rights to enjoy and use all that he found in his (including beneath) property in any manner that he chose and could even indiscriminately use it. This unlimited use right went to the extent of:

"If in the exercise of such right, he intercepts or drains off the water collected from underground springs in his neighbours well, this inconvenience to his neighbour falls within the description of damnum absque injuria (damage without any legal injury), which cannot become the ground of an action" (Acton's Case,1843)

This position of law was continuously applied by the English Courts and reaffirmed finally in Bradford $v$. Pickles where the court held that:

"An adjacent landowner has no property in or right to subterranean percolating water until it arrives underneath his soil... [And] therefore no property or right of his injured by the abstraction of the percolating water before it arrives under his land" (Bradford's Case, 1895)

This then firmly established the common law position that it is not unlawful for a property owner to even abuse his property rights, even maliciously, to the detriment of others or even compromising any public interests that may be involved. This position is commonly referred to as the "English Rule".

Most of the American states more or less follow the Common Law of England. There are no Federal laws that address the question of groundwater ownership or allocation and groundwater management is typically left to the States (Rasband, Salman \& Squillace, 2004). To respond to the changing pattern of groundwater use and possible conflicts over the use of the resource, the legislatures and Courts of some of the States experimented with the common law doctrines of 
absolute ownership, reasonable use, correlative rights and prior appropriation (Malone, 1990). By the beginning of the 20th Century, the Courts had started applying the doctrines of correlative use and reasonable rights to overcome the problems caused by the unduly harsh nature of the English Rule and the exhaustible nature of the resource in question. Both these doctrines emerged from the surface water law of riparian rights that was practiced in England and some parts of the United States (Swenson, 1998).

The Riparian system gave the landowner near a water body to draw reasonable amounts of water from his land, as long as no interference is made with the similar rights of other riparian land owners. The two American Doctrines together are referred to as the "American Rule" (Higday's Case, 1971). The reasonable use principle is based on that principle of Sic utere tuo ut alienum non laedas (so use your own as not to injure another's property). It flows from this principle that a landowner is entitled to draw reasonable quantities of water which can be put to a beneficial and reasonable use for the overlaying land (Trelease, 1974). However, the limitation of the Rule lies in that in its application the principle question is what constitutes 'reasonable use'. In deciding what is reasonable, the amount of water drawn is assessed with reference to nature and comparative value of the uses and hence massive extraction for bottling and sale can also be reasonable (Michel's Case, 1903; Malone, 1990). Further, the use of ground water on non-overlaying lands is considered as per se unreasonable (Malone, 1990). This then has the effect of placing undue hardships on farmers who irrigate multiple parcels of lands from one of the several parcels of land belonging to him. Thus, while the rule protects the adjecent landowners from large withdrawals by any single entity for use over non-overlaying lands or from large scale withdrawals for municipal supply of drinking water etc., it does not prevent massive extraction for industrial uses or manufacturing processes, as long as the water is used by the establishments on the overlaying land, as these can fall within the ambit of "reasonable use".

The Correlative Rights doctrine was developed in the State of California and it applies the same concepts of 'reasonable use' except that it apportions water supply during an event of shortage. This rule then ensures that each landowner receives an equitable share of water (Trelease, 1974). The Doctrine of prior appropriation recognises seniority in groundwater uses that are first in time. A Water Right is created under prior appropriation when a user extracts water and puts it to beneficial use (Trelease, 1974). It is noteworthy that the principle itself developed in the context of the need to protect investments made in diverting water sources, chiefly for industrial purposes. However, the doctrine is not easy to apply and gives no guidance on what standards are to be applied while determining the quantity of pumping to be reduced by each landowner (Lailos \& Tomar, 1992). In City of Pasadena $v$. City of Alhambra it was held that apportionment must be proportional to the actual historic use (Pasadena Case, 1949). This rule can then create perverse results as there would only be a greater incentive to increase pumping as greater prescriptive rights would be established. Further, the rule cannot be invoked to prevent a massive exploitation that can result in resource depletion. Further, the doctrine has the effect of "freezing" existing users into place and the new users are burdened or limited from making extractions.

Some of the States, most prominently the State of Florida legislated a permit system to fill the loopholes in the American Rule. The Water 
Resources Act of the State of Florida divided the State into water districts with each district requiring permits for consumptive uses. Reasonable restrictions may be imposed in accordance with the objectives of the district. To obtain a permit, applicants are to show that the proposed use of water is a reasonable and beneficial one and does not interfere with any settled legal use of water and that it is consistent with public interest. However, determining "reasonable -beneficial use" is still tricky and often large scale withdrawals can fall within the ambit of the expression. While this rule can indeed protect domestic consumption interests, when it comes to a tussle between agricultural and industrial use, the rule provides less than satisfactory answers. It is also noteworthy that the American Rule also does not touch on the question of who should own the groundwater.

\section{The Public Trust Approach to groundwater}

Considering the limitations of the English and American Rules in ensuring equity and resource conservation, the common law legal systems soon started devising alternate approaches to groundwater. The most prominent of these are regulatory frameworks based on the doctrine of public trust.

Public trust is based on the historical Roman and English notions that there are certain common properties that are held by the State for the benefit of the public. Notably, the doctrine evolved in the Roman law specifically in the context of navigation, fishing and commerce rights on livers, lakes etc (Wilkinson, 1989). The use of public trust in the context of environmental protection is a recent innovation which began as a result of the seminal work of Professor Joseph Sax on the Doctrine (Sax, 1970). Over the years, the doctrine has then grown and encompassed most of the natural resources within its realm (Stevens, 1980; Frank, 2012; Blumm, 1989).

Public trust essentially describes the relation between the citizens and the water resources belonging to it. The doctrine emphasises on duties and not on rights (Singh, 1991). The doctrine postulates that the state has a duty to protect, preserve and manage the use of the trust property to further the public interest involved. In the context of water this translates to mean that

"the state, which holds the natural waters as a trustee, is duty bound to distribute or utilise the waters in such a way, that it does not violate the natural right to water of an individual or group and safeguards the interest of the public and of ecology or nature" (Singh, 1992)

Though the Constitution of India makes no explicit reference to the doctrine, it was read into Indian Law by the Supreme Court decision in M.C.Mehta v. Kamal Nath and Others. Over the years, the doctrine was applied more extensively by the Court through a series of decisions mostly in the context of the right to access and use water bodies, parks etc. (M.I Builders Case, 1999; Intellectuals Forum Case, 2006). The doctrine was then extended over natural gas (Reliance Case, 2010) and the general observations made by the court therein were indicative of the direction the law would soon take - to cover all depleting and non-renewable natural assets. The effect of the doctrine would be that the government would be prevented from allocating the resource for exclusive private exploitation or from transferring ownership rights to any particular private entity in toto. Functionally, the doctrine essentially sets standards of conduct for state action, and makes room for the courts to judicially review governmental action based on this standard. 
In Reliance Natural Resources Ltd. v. Reliance Industries Ltd, Justice Reddy espoused the doctrine in the context of Article 297 and concluded that the implications of the doctrine would be that the state is thereby prevented from: (1) Transferring the title of those resources after their extraction unless the Union receives just and proper compensation for the same; (2) Allowing a situation to develop wherein the various users in different sectors could potentially be deprived of access to such resources; (3) allowing the extraction of such resources without a clear policy statement of conservation, which takes into account total domestic availability, the requisite balancing of current needs with those of future generations, and also India's security requirements; (4) allowing the extraction and distribution without periodic evaluation of the current distribution and making an assessment of how greater equity can be achieved, as between sectors and also between regions; (5) allowing a contractor or any other agency to extract and distribute the resources without the explicit permission of the Union of India, which permission can be granted only pursuant to a rationally framed utilization policy; and (6) that no end user may be given any guarantee for continued access and of use beyond a period to be specified by the Government. Though how binding are justice Reddy's prescriptions in this judgment still remains debatable, they still remain to be of considerable legal value, contributing especially towards the growth of the law.

In 2012, the Supreme Court expanded the ambit of public trust once again to cover all natural resources. It was held that "State is the legal owner of the natural resources as a trustee of the people and although it is empowered to distribute the same, the process of distribution must be guided by the constitutional principles including the doctrine of equality and larger public good." (The 2G Spectrum Case, 2012) Since the law declared by the Supreme Court is the law of India and binds all other authorities (Article 141 of the Constition of India), it goes without saying that public trust doctrine is firmly a part of Indian law and according to the 2012 judgment, groundwater being a natural resource, is already under public trust. This then also means that, irrespective of whether the States choose to legislate along the lines prescribed by the 2011 Draft Model Bill, public trust is applicable to groundwater and the State is duty bound to treat the resource in accordance with the duties imposed by the doctrine.

Public trust over groundwater is not a startling proposition - Courts in India and elsewhere have reflected on the connection (Swenson, 1998). In the United States, the Hawaii Supreme Court applied the doctrine to all groundwater resources of that State (Waiahole Ditch, 2000). The Court observed that the "common law distinction between ground and surface water developed without regard to the manner in which both categories represent no more than a single integrated source of water with each element dependent upon the other for its existence". The legislature of the State of Vermont also adopted this approach and declared that its groundwater resources were encompassed by the public trust doctrine. (Frank, 2012). In India, the High Court of Andhra Pradesh was first to take the lead: In M.P. Rambabu v. The District Forest Officer it was held that 'deep underground water' was the property of the State under the doctrine of public trust. It was also held that landowners had the right to draw reasonable quantities of water for their use, but would be held liable if they contaminate their neighbor's wells or restricts the flow of water to the neighbor's land. It was held that the public had a right under 
the doctrine to enforce a right to prevent infringement of their interest in a situation in which the public at large would be affected (Rambabu Case, 2002). In the Coca-Cola litigations before the High Court of Kerala, the single judge of the Court had also relied on the doctrine of public trust to conclude that the Panchayat could regulate the quantity of water that could be drawn by the bottle manufacturing unit. (Coca Cola Case, 2003).

As it can be seen, on the face of it doctrine places restrictions on the sovereign on the manner in which these resources can be explored and exploited. Gazing through the postulates, one can see that the doctrine would seek to ensure access to all participators, ensure responsible use of the resources, prevent arbitrary allocation of resources and ensure equity. The doctrine also takes the ownership of groundwater away from the private realm and renders it incapable of ownership by anyone. It is only held in trust by the State to be apportioned in Public Interest. However, is the public trust approach the ideal way forward for India? This question shall be discussed in the next section.

\section{The Common Law in India and attempts at reform}

The legislative attempts at the time of the British Raj, were mostly to gather and codify the English common law and apply them to India (Baxi, 2005). The approach of the British Indian Enactment to groundwater was hence dominated by the English common law approach that was described previously. Following the Common Law approach, early British laws on irrigation established different set of principles over surface and groundwater (Singh, 1991). For Groundwater, the Indian Easements Act codified the English Rule. Section 7 of the Act describes an easement to be a restriction of the rights enumerated in that Section and sub-section $(\mathrm{g})$ mentions the "The right of every owner of land to collect and dispose within his own limits of all water under the land which does not pass in a defined channel and all water on its surface which does not pass in a defined channel". Thus Section 7 (g) implicitly recognises the position of law to be same as that of the common law. This formulation also found judicial favour in some of the pre-independence decisions, most notably in Kesava Bhatta v. Krishna Bhatta where the Madras High Court after examining the relevant precedents concluded that:

"The General Rule is that the owner of a land has got a natural right to all the water that percolates or flows in undefined channels within his land and that even if his object in digging a well or a pond be to cause damage to his neighbour by abstracting water from his field or land it does not matter in the least as it is the act and not the motive which must be regarded. No action lies for the obstruction or diversion of percolating water even if the result of such abstraction be to diminish or take away the water from a neighbouring well in an adjourning land."

Even Six decades later, this thinking prevailed and following it, the division bench of the High Court of Kerala in the Coca Cola Case held that in the absence of laws that prohibited extraction, the company had a vested legal right to extract the quantity of groundwater which it required. It was observed that:

We have to assume that a person has the right to extract water from his property, unless it is prohibited by a statute. Extraction thereof cannot be illegal. We do not find justification for upholding the finding of the learned Judge that extraction of ground water is illegal...We cannot endorse the finding that the company has no legal right to extract this wealth.... The Panchayat had no ownership about such private water 
source, [and the law laid down by the single judge is] in effect denying the proprietory rights of the occupier...." (Coca Cola Case, 2005a).

Such an approach to groundwater regulation may have been prompted by two factors: Firstly an ignorance of groundwater hydrology and secondly the limited nature of groundwater extraction which then presented no foreseeable threat of resource depletion (Phansaklar \& Kher, 2006). Post- Independence, India however witnessed a surge in the use of groundwater. With an expansion of both agriculture and industrial sectors, the resultant increase in the use of groundwater, the number of open wells and tube wells rose and groundwater was being exploited like never before. The latest figures indicate that groundwater dependency for drinking water as well as irrigation touches $60 \%$ in most parts of the Country and even up to $90 \%$ in the rural areas (CPCB, 2005). With these massive changes, one would have expected the legal system also to respond to the changed Circumstances - which in some it did attempt to do. The Constitution of India makes no specific reference to groundwater per se and it is generally assumed that water includes groundwater (Iyer, 2003). Entry 17 in the State list makes water (except interstate rivers) the legislative domain of the State. This means that changes to law of groundwater will have to be made by the States and the Parliament is barred from legislating on the subject

Reforms to the groundwater laws can be said to have begun in the $70 \mathrm{~s}$ when the Ministry of Water Resources of the Central Government circulated a Model Bill to Regulate and Control the Development and Management of Ground Water ( hereinafter the "Model Bill") amongst the States. The Model bill was then revised in 1992, 19962005 and finally in 2011. The Bills up to the 2011 revisions follow a model of setting up an authority at the State Level which is empowered to notify Areas to regulate and control the Development and management of groundwater (Section 5, Model Bill). Users of ground water in the notified area are to obtain a permit from the said authority before sinking a new well and users from existing wells are to inform the authority of the same (Section 6, Model Bill). The authority can grant or refuse permission after evaluating the public interest involved (Section 6, Model Bill). Failure to comply with these provisions can attract penal sanctions (Section 21, Model Bill).

Some of the States have made enactments following the Model Bill: The Kerala Groundwater (Control and Regulation) Act, 2002; The Goa Groundwater Regulation Act, 2002; the Himachal Groundwater (Regulation and Control of Development and Management) Act, 2005; The West Bengal Groundwater Resources (Management, Control and Regulation) Act, 2005 \& The Andhra Pradesh Water Land and Trees Act, 2002. It has been observed that most of these State legislations substantially reproduce the provisions of the Model Bill with few cosmetic changes (Cullet, 2012). The Law of West Bengal makes a significant departure from this with a decentralised mechanism as opposed to a single state suthority. Similarly, the Law of Andhra Pradesh, The Andhra Pradesh Water Land and Trees Act, 2002, is also unique in that it provides for an integrated regulatory framework that covers land, water and tress under a single Statute. It appears that some States have rejected the idea at least for the time being. The main feature of these laws is the limited extent of their applicability - only to 'notified areas' which in turn also becomes their major limitation. State governments are not well known for making these notifications on time. It is interesting to note that as the Plachimada dispute was raging, the 
Kerala Groundwater Act was already in force, however, no notifications under the Act were issued and no functional authorities were set up. It has also been observed that in States were notifications were issued, the exploitation simply moved on to the non-notified areas. Apart from these, the general criticisms of ineffective implementation of laws and poor monitoring apply with full force in this context too. The Expert Group on "Groundwater Management and Ownership constituted by the Planning Commission of the Government of India was of the opinion that the Model Bill has not found favour with most of the States as it is believed that the mechanism envisaged under the Act would only cause severe hardships to farmers (Planning Commission, 2007).

These legislations take an approach of only enabling a restriction on the number of wells - which can be rendered ineffective by individuals by the use of more powerful pumps. Further, they bestow a right of use to persons who already have sunk a well, and exclude the future potential users - which is indeed iniquitous. It has also been revealed that these kinds of regulations negatively impact the poor farmers, who are required to deal with more regulations (Moench, 1992). But most of all it needs to be noted that the Model Bill and the State Acts are silent about ownership of the resource. Thus, once the wells are sunk, the common law position takes effect - that all the groundwater beneath the soil belongs to the owner of the land and that he is free to extract it free of any quantitative restrictions.

This legal terrain of bundling water rights with land rights also has the side effect of leaving the landless without access to groundwater. On the one hand there is immense dependence on groundwater by way of public wells and on the other, a right to draw groundwater emanating only from ownership of land. In India, with vast number of landless people, this regime excludes the landless lot who have a direct stake in the matter (Background Note, 2011). It can also give the landowners a disproportionally larger access to groundwater and exclude landless farmers from accessing credit for development of groundwater irrigation (Upadhyay, 2009).

The last revision of the Model bill of the year 2011 makes a significant deviation from the previous ones in adopting the public trust approach. The Draft Model Bill starts with recognising groundwater as public trust (Section 9, Model Bill.) It proclaims that "Groundwater is the common heritage of the people of India held in trust, for the use of all, subject to reasonable restrictions to protect all water and associated ecosystems. In its natural state, it is not amenable to ownership by the state, communities or persons." However, apart from this, the 2011 revision makes no changes to the administrative mechanisms espoused by the previous Drafts.

Public trust implies a rise of governmental authority (Swenson, 1998). Public trust is dictated by public interest and determining public interest can be a very tricky affair. For instance large withdrawals for drinking water supplies to neighboring urban settlements can be argued to be in public interest. Allowing soft drink companies to extract water as it brings foreign investment and hence valuable foreign exchange can also be a public interest argument. It is at least difficult to take perfect positions on these questions. The public trust at once places duties however it also creates a large sphere of discretion in defining public interest. The question then is whose public interest is being furthered. In the Plachimada and the Plachimada like situations, it is notable that the State governments have supported these initiatives as they brought 
investments and jobs. However, at loss here are the people of the communities where these industrial units were situated. The community that depended on the groundwater resource had no voice when the public interest question was being debated on. This is typically because water problems are local problems and actors who live far away from the site of the issue feels no immediate need to take a position that favors the community affected by it. The Public trust approach along with the laws in the Model Bills only strengthens the State and its machinery. The History of the Plachimada struggle and the similar ones has shown us that the positions taken by the State in these situations are not always ones that favor the community and persons that depended on the water resource. The Public trust approach is hence per se not the ideal answer to the problem in focus here.

With that being said, one must then look for alternate mechanisms for regulating groundwater. The regulation of groundwater is indeed manifesting itself to be a problem of global scale. Several other countries have encountered this problem and they devised a variety of approaches to answer this challenge. Examining these jurisdictions and attempting to learn from their experience is a significant step in out enquiry. The next section is intended to serve that purpose - of looking beyond our boundaries for solutions.

\section{The Regulation Of Groundwater: International Approaches}

Control over water is in many ways control over an entire civilization. Countries elsewhere, in the course of history, have experienced the felt need to control the ownership, use and management of water. A variety of approaches have been employed for this purpose. This section makes a study of this variety of approaches. The purpose behind this section is to examine the current trends, practices and mechanisms employed over groundwater management so as to identify whether anything from these experiences can contribute to the proposed framework for India.

The ability to regulate, allocate and control groundwater resources depends on both the existence of a legal framework to deal with the resource and the particular approach employed by each framework for ownership and allocation of water. This framework can be a separate water law or provisions that are spread across different laws - both legislative and customary. The approach adopted here is to concentrate on legislative frameworks as this is certainly the approach suitable and envisioned by the modern day Indian Republic. If one takes a synoptic view of these country laws, one finds that the provisions of law can be by way of simple legislation; or Constitutional provisions that mandate a particular approach: a course of action with duties or responsibilities of the different wings of government being outlined along with the applicable principles; and a conjunction of both of these. While most of the laws have these central features, countries have adopted a variety of approaches to governance, ownership of the resource and its management. Though not a perfect categorization, one can broadly classify them as centralized and decentralized approaches. The attempt here is to study the most recent of these legal and management frameworks so that the focus is on the modern day and current line of thinking. As stated before, the broad classification that is made here is slightly imperfect as the idea of a centralized system of management does not appear to be as centralized as one might initially imagine it to be. Large countries with diverse demography and geography appear to be 
leaning in favour of bringing in some elements of decentralization, while as such their law echoes centralization.

It appears that the highly centralized approach is preferred at present only by small countries. A case in point here is the African State of Cameroon. Being a relatively small country in geographical area, the management of the resource is a centralized one with the powers to regulate use, management of infrastructure being vested in the Ministry of Energy and Water. All water, including the groundwater is in the ownership of the State. Statute No.98-005 of 14 April 1998 (hereinafter the 1998 Law) and Statute No, 79-10 of June 1979 (hereinafter the 1979 Law) regulates all water resources including spring waters. Under these laws, the state is empowered to issue regulations governing the use of groundwater for industrial or commercial purposes. For such uses, a prior authorization and payment of tax is contemplated (Art. 10 (1), the 1998 Law). Further, such uses are allowed only after a scientific evaluation of the impact of extraction on the environment and the quality of life of the people (Art. 10 (3), the 1998 Law). Further, in certain circumstances, the government is empowered to forbid the extraction of water. These circumstances are risks of drying, of pollution or to public health (Art. 9, the 1998 Law).

Even for those countries with a stated policy, culture and programme of centralization, it is seen that over the years, there has been some attempts to imbibe elements of decentralized management. Mexico is a case in point: Article 27 of the Constitution of Mexico mandates that the federal government is to regulate the distribution of water, the extraction \& utilization of groundwater and the communal possession of water rights. Pursuant to this mandate, the Federal Government has enacted a number of Laws to deal with water rights (Tortajada, 1999). The principal legislation amongst these is the National Water Act, 1992. The Act applies to all national Waters, including groundwater (Art. 2, The National Water Act). Under the Act, the Federal Government approves a national program that integrates regional, basin, State and sectoral subprograms (Velasco, 1999). Article 7 bis added into the law public interest considerations as a goal. Mexico, has however, brought in elements of decentralized management over the years. The federal government has decentralized water resources management to the Commissions and the Organismos de Cuenca (Basin Organizations) at the State level (Villareal \& Valesco, 1994). These organizations function at the State, regional and basin levels and are tasked with the protection and improvement of the water resources. (Gorriz, Subramanian \& Simas, 1995). Irrigation districts (which cover both surface and ground water) has been established, which act as the basic unit of management. (Art. 71-73, The National Water Act). Individuals can obtain a right to use water (in the form of a concession) from the National Water Commission through the Basin Organization (Art. 20, the National Water Act). Groundwater can freely be extracted, however, the Government is empowered to regulate this in public interest (Art. 18, The National Water Act). An independent consultative body called the 'Consultative Council on Water' freely advice and evaluate projects and water extraction from a strategic point of view (Tortajada,1999). This Council has members from the private sector, the social sector, academia and 'people of an altruistic vocation (Art. 14 bis 1, The National Water Act).

China is another country that follows such an approach. Article 9 of the Constitution of the People's Republic of China states that all the waters 
of China are "owned by the State, that is, by the whole people". Article 3 of The Water and Soil Conservation Law of the People's Republic of China (hereinafter, the Soil Conservation law of China) states that the water resources of China, include both surface and groundwater. Under the Constitution, the state is responsible for ensuring the rational use of water and individuals are prohibited from appropriating or damaging it in any manner. The State council exercises the right of ownership and the department of water administration has established a licensing system for the allocation of water and a fee needs to be paid to draw water (Arts. $7 \& 8$, the Soil Conservation law of China). Any individual that uses water is obliged not to infringe public interest or the lawful rights and interests of other users (Art.28, the Soil Conservation law of China). The Water Law of the People's Republic of China (The Water Law of China) regulates all water resources. This law obliges the state to formulate long-term strategic plans for use, protection and management of the water resources (Frederiksen, Berkoff \& Barber, 1993). However, the unit of conservation and management is the river basin (Art. 14, The Water Law of China). The law calls for a unified treatment and development of surface and ground water. (Art. 23, the Water Law of China) and it also establishes a set of priorities in water uses, the highest being accorded to domestic needs (of both urban and rural population), which is followed by agriculture, industry, environment and navigation. (Art. 21, the Water Law of China). The result of all this is a unified system of control for the allocation and use of water. The Central Government formulates quota for each activity which is then allotted between provinces, autonomous regions and municipalities (Article 47, The Soil Conservation Law of China). These lower levels of government then decide on how the water allotted to them shall be used. This then translates to mean that all departments of water administration above the level of a county and the administrative organizations of river basins are to formulate annual water allocation plans, consistent with the overall water plans (Article 46, the Soil Conservation Law of China). The State has adopted a system of administration that combines river basin administration with the administration through administrative divisions (World Bank, 2002). The Department of Water Administration is responsible for the protection, management and periodical inspection of all the water resources. However, it has delegated these responsibilities to the lower levels of governments with regard to waters within their jurisdictions. The departments of water administration at all levels of government and the administrative departments of river basins are responsible for controlling the withdrawal of groundwater (Art. 36, the Soil Conservation Law of China).To protect groundwater, enterprises and institutions are prohibited from discharging or dumping wastewater into wells or pits. The law further provides that if any mining or construction project results in a lowering of the level of groundwater or results in a loss of livelihood to persons, the enterprise is to take corrective actions to restore the groundwater and to compensate the affected persons (Art. 31, the Soil Conservation Law of China).

Brazil is yet another country that had a highly centralized and state centric approach, yet over the years, elements of public participation were brought in over time. With a federal system of government, Brazil had the power over water resources split between the Union and the State Governments. All water in Brazil is owned by the Government: Article 20 of the Constitution of Brazil States that water is the property of the union and Article 26 states this to include groundwater. Article 21 
mandates the Union to establish a national system for the management of water resources and define the criteria for granting rights over its use". Pursuant to this obligation, the National Water Resources Policy (the NWRP) (Law No. 9433 of January 8 1997) and the National Water Agency Law (hereinafter the NWAL) (Law No.0084, July 17, 2000) were enacted. The NWRP states groundwater to be public property and a limited resource with an economic value and it asserts that "the award of the right to use water in no way implies partial alienation of the water itself" (Arts. 1\& 8). It further states that "The right to use groundwater for both personal consumption or commercial use is subject to a governmental award of the same, except when it is for meeting the needs of small population groups in rural areas (Art.12 and 14, NWRP). The law also calls for a management that makes room for multiple uses of the resource (Art. 1). The basic territorial unit for the implementation of the law is the river basin and the management envisaged is a decentralized and participatory one - involving inputs from users and communities. The law thus envisages a management that suits the specific conditions of each region and hence the authorities are free to choose from a variety of management options. There is the option of imposing a permit for the extraction or use of water along with a user's fee. Usage rights, hence are dependent on an award of the same and awards are made according to the priorities established by the Water Resources Plan. The executive branches of the State and Federal Districts award the user rights and also regulate their usage. The River Basin authorities comprises of government representatives, river basin committees and also the indigenous communities who have an interest in the resource (Arts. 13, NWRP).

Like it was pointed out at the beginning of this section, grouping countries under the "centralized" and "de-centralized" heads is no longer a good classification as even countries that had a stated ethos in favour of centralization and state management are gradually moving towards incorporating at least a few elements of decentralization and participation. A survey of the most recent of water management laws point in the direction of these two objects. Decentralization of water governance and resource ownership appears to be the current line of thinking internationally. Some countries with recent laws on water management are surveyed here to understand the modalities and methods of decentralization.

Armenia is the country to start with. Two Statues here deal with water governance: The Water Code of the Republic of Armenia, 2002 and the Law of Republic of Armenia on Water User's Associations and Unions of Water Users Association (WUA Law). The former provides for conservation and effective management along with ensuring ecological sustainability (Article 6, The Water Code of the Republic of Armenia). According to Article 4 of the Water Code, all water resources are the property of the state and to use or extract them a permit is required. However, for uses that are not motivated by the gaining of profit, no permit is required (Art. 22). A landowner can acquire a permit to use the groundwater that relates to his property from the Water Resources protection authority or the Water Basin management authority; both of them decentralized bodies that attract participation from all segments of users. This law also calls for public participation from all segments of water users (Art. 5 (24) and mandates the formulation of a national policy that sets out the methods to achieve it. The WUA law has been made pursuant to that obligation. The WUA law regulates the establishment and operations of the Water Users Associations. The 
authorities that issue user permits are linked to the WUAs by Article 11 of the Water Code: Citizens representatives and the WUA are also members of these authorities and they also have a right to an advisory vote. All applications for a permit are put to the notice of the public, who also have a right to be heard. The permit issued states the limits of the quantity of water that can be drawn and money have to be paid in proportion to the quantity drawn (Article 32). Since the laws states that water resources cannot be used in a manner that decreases the national economy, while issuing permits, the authorities would have to take this also into consideration (Art.18).

The Strongest advocates of decentralized management appear to be the European Union. The European Directive 2000/60/EC of 23 October 2000 established the framework for Community action and an integrated framework for water management (The EC Directive). All the European Union Member States are obliged to implement this directive into its domestic legal framework. The policy calls for sustainable development and management of resources, taking a precautionary approach at conservation and applying the principle of "polluter pays" for mitigation (Reichert, 2005). As the Directive is meant for the whole of Europe to implement, it does not contain specific provisions on the ownership or water or water rights in general. The directive calls for planning and implementation of measures that ensure protection and sustainable use of water and the river basin is the basic unit of governance stipulated ((Preamble, EC Directive). Hence, the natural boundaries of a water system are the unit of management, rather than political or administrative boundaries. The directive articulates the principle that decisions are to be taken as close as possible to the location where the effects of the decision would appear (EC Directive, Preamble, Recital 13). Further, it also provides for ensuring public availability of all information relating to planning, decision making process and the decision (EC Directive, Preambulatory recital 46). The Member States are to identify an appropriate authority for each river basin and adopt the necessary administrative arrangements for each river basin district Art. 3, EC Directive). The Directive further elaborates on the duty of each member sates to prevent pollution, ensure sustainable use, to study the characteristics of the river basin and the impact of human activities on the water resources (Articles 4\& 5, EC Directive). Since this directive is only a framework and the specifics of implementation are left for the member countries, the implementation mechanisms of two states are surveyed here to gather a better picture of the working of the directive.

In France, the Statue of January 3, 1992 which was (as amended in 2000 \& 2003) implements the EU Directive. The law envisages that the State manages water on behalf of the nation and water rights are determined in accordance with the regulatory scheme outline in that law. Groundwater is owned by the public and the overlying land owners have only a limited right to use it (Salman \& Bradlaw, 2006). To use groundwater, a grant has to be obtained from the State, which needs approval at the regional level. For commercial uses, an environmental impact assessment needs to be conducted and constant monitoring of the quantity of water drawn is also required (Salman \& Bradlaw, 2006). This law focuses on those basic issues outlined in the Directive by making changes to the Scheme directeurs d'amenagement et de gestation des euax (the water management master plan) (Salman \& Bradlaw, 2006). A local water committee is responsible for the development of the water management plan. This committee has representatives from the local 
department, the government and the local water users. A water management plan is drawn up in collaboration with the relevant water basin committees. A local committee assists the authorities in implementing the plan and regulating the uses of water within a River Basin. This committee also consists of representatives of water users, of the region and the local chambers of commerce. The views of the general public are also sought in the course of drawing up the management plan.

In Germany, the Constitution as such contained no provisions on natural resource management, except for a few principles, which are of "soft law" nature (Salman \& Bradlaw, 2006). However, the Constitutional Court of Germany has declared that the government has the power to regulate the use of groundwater and that groundwater was a public good (Nassauskiebung Case, 1981). Being a federal state, the Basic law of Germany divides powers and responsibilities between federal and provincial (state) governments. The Basic Law states that Water resources are subject to Federal Legal Control. Accordingly, the federal government makes the law and the States implement them. The Act on Regulation of Matters Pertaining to Water (Federal Water Act) of 2002 implemented the EU Directive in Germany. The law calls for management of all water resources in a manner that advances public interest. The ownership of land and water are not interconnected and extraction of water requires a license and a permission (Federal Water Act, Pt.I, Art. 1a (4)). This license confers no ownership over the resource or a guarantee for particular quantities of water to be made available and the permits are granted wit limitations of place, time, quantity and manner of use. A permit is normally refused where extraction can cause detrimental effects on the other users or if it imparts the environment (Federal Water Act, Pt.I, Art. 3). The persons who can be affected by the grant of a permit are to be heard before granting it and if required, an environmental impact assessment is also conducted (Federal Water Act, Pt.I, and Art.9). The permit can be revoked or cancelled on the grounds of public interest (Federal Water Act, Pt.I, Art.12). As contemplated by the EU Directive, the management system is a decentralized on : The Local bodies are tasked with maintaining the water bodies (Federal Water Act, Pt.II, Art .29) Germany has been divided into ten river basin districts and each State is required to assign the river basins within its territory to one of these districts. Each river basin district is required by the law to prepare a program of measures for the management of the water resources in the river basin.

Decentralized and participatory approaches to management are not just a European initiative. Perhaps the finest example of a decentralized approach is in South Africa. The South African Constitution is unique in guaranteeing to all its citizens "a right to water". There are several laws in South Africa that touch on water rights (Clark, 1999). The principal amongst these is the National Water Act (hereinafter the NWA). The NWA places the Government as the "public trustee" of all water resources. The NWA establishes the 'Basic Human Needs Reserve' and 'Ecological Reserve' and water from these reserves cannot be allotted for other purposes (Stein, 2000). All consumption of water exceeding the de minimis extent or that which is pursuant general authorization no permit is required. General authorizations are issued with respect to a particular geographical area and that too only after public consultations and publication in the official gazette. For all other uses a license from a competent authority is required. A license is issued only after the rights of existing users, public interests and the impact of extraction on the 
resources is taken into consideration (Sec. 39, NWA). Before granting a license, the application is published; the affected parties are accorded an opportunity to oppose it. A reasoned order (for either granting or rejecting the license) is required and conditions for the protection of the resource and the rights of the other parties may also be imposed.

Catchment Management Agencies (CMA) are to established for each water management area, the objective of which is to ensure decentralized governance involving the local communities (Chapter 7, NWA). CMAs are independent bodies, whose governing boards are elected by water user groups (or appointed by the minister). The composition of the board is to reflect the interests of the various stakeholders in a particular catchment area.

\section{The Lessons from international experience}

The appropriate approach to regulation would indeed be influenced by a variety of factors, including the size of the country, the diversity of the population, the prevalent dominant culture and demography. While most of the smaller and less diverse countries have preferred to centralize their water management, larger countries have, especially over the last few years, exhibited a preference for decentralization. The approach of all 21 st century models is also in favor of decentralization. Irrespective of the approach to governance, all the countries surveyed above have treated groundwater to be the property of the state or as regulated by public interest. The emphasis on protecting and furthering public interest while determining the use, management and appropriation of water has been a central theme of almost all the legal systems surveyed in this section. For achieving these objectives the standard mechanism used is a permit system for the extraction and use of groundwater. Some of the countries surveyed have rationalized the permit system by exempting domestic and de minimis use from the requirements of a permit. Notably, the permits in the decentralized system are granted only after publication, invitation of objections and a voice for the local interests.

In India, neither the Model Bill, nor any of the State Legislations that follow them have such provisions. Though a permit system has been established by most of these laws, there are no avenues for the local interests to be reflected in the decision making process. "Public Interest" is mentioned in some of these laws as a consideration, however, as pointed out before, the term is of no definite meaning and investments and gaining of foreign exchange for the country can be considered overriding public interests compared to the water needs of a small village. Importantly, the Model Bill and the State Governments centralize the establishment for governance when the world is moving towards decentralization. Further, there is also little scope for participation in decision making or space for the local interests to be articulated. That being said, the question now remains as to what is that better approach for water governance in India. the next section of this thesis explores answers to that question.

\section{Reconceptualising The Groundwater Law For India}

\section{The case for decentralization}

The existing Indian groundwater management framework and the direction of the reforms were surveyed as well as the difficulties, shortcomings and limitations of a centralized model (by centralization it is meant centralization within each state too) of groundwater ownership and governance with respect to Indian conditions have been discussed 
earlier. This requires us to think about alternate strategies and approaches to groundwater management. The search for such alternate strategies must be from both within and from recent international experience along with novel strategies. India, with its vast expanse, diversity of demographics and increasing instances of water conflicts, requires a strategy that aims to find solutions of management within each community that faces particular issues. In tune with this, the strategy suggested here is one of a decentralized and participatory approach to water governance. It has been observed that a more transparent, participatory and inclusive approach to water governance gives better chances for a regulatory regime to be accepted, supported and most important of all owned by the people (Mostert, 2004; Priscoli, 2004). Such ownership and acceptance would in turn remove several other obstacles that would otherwise be faced in implementation.

Participation and decentralization is the present day internationally accepted norm for ideal governance. Principle 10 of the Rio Declaration calls for participation of all citizens at decision making at all levels on matters that touch the environment (Rio Declaration, Principle 10). One of the four principles espoused at the Dublin Summit was to structure water development and management based on participatory approach that involves users, planners and policy makers at all levels (Dublin Statement, Principle 2). Decentralization is based on the principle that "nothing should be done at a higher level of government that can be done satisfactorily at a lower level" (Rogers, Bhatia \& Huber, 1998). It is this thinking that has prevailed in the creation and structure of several basin management agencies across the Globe (Jaspers, 2003). It is further argued that such an approach "increases the likelihood that the system under their responsibility will be well maintained and [that it would] contribute[s] to community cohesion and empowerment in ways that can spread to other development activities" (World Bank, 1993). It has now been put forth that ensuring participation is integral to the success of any legislation or policy (Priscoli, 2004).

What are then the approaches to ensure participation \& decentralization? The approach adopted in most countries towards ensuring participation is the creation of water users associations. Water users associations have been established as legal entities that has responsibility over the operation and management of the facilities and resources within their jurisdiction. In the jurisdictions surveyed earlier, it is seen that the law lays down procedures for functioning of water users associations (WUAs) and its relationship with the governmental authorities. The byelaws of each association further expand the relationship of the association with its members and the executive committees of the associations. However, in some of the countries, a further step is taken and ownership of the systems and resources itself falls on the concerned WUA rather than just the operation and maintenance powers. Another approach adopted was to set up advisory committees with representatives of the people, the public, experts and industry representatives. Such bodies would then assist the governments in the framing of policies, plans, programs and in the decision making process. Countries surveyed earlier have adopted techniques such as notice to public before issuing water permits, mandatory invitation for public comments before embarking on legislation or policy making to strengthen participation. Needless to say, for such approaches to be successful, it is essential that the law must clearly define the limits of the watershed and aquifer, the composition of the agency and the responsibilities of the basin authority. Further, the responsibility of the 
authority must extend to both preservation and protection of the resource that it operates. This approach would thus incorporate two of the Dublin Principles.

\section{Strategies for India}

As stated before, devising an appropriate decentralization strategy for India involves answering a multitude of questions ranging from deciding on the entity that is expected to perform this role and aligning it with requirements of conservation and sustainable management of groundwater resources. India has highly varied climatic, topographical and geological features. Managing such a vastly different ecological profile calls for different approaches and strategies, which in turn strengthens the call for a decentralized approach towards governance.

At the heart of this issue lies a further important question about who should own the resource in question that we are attempting to protect, preserve and put to equitable and judicious use. If we are to find solutions to questions like what is the best way of management, who owns the resource in question and what rights are available against the state and government for the owner, the debate will have to go beyond just a simple question of management. The need for a right based approach to access, use and conservation of water is perhaps an important corrective needed to the present framework of Indian laws. In the absence of this question being addressed, the current attempts at decentralization goes to be nothing beyond a shifting of responsibility with the burden of ensuring supply with no power (nor incentives) for resource conservation and efficient use. These organs then serve a purpose of nothing more than a body to implement decisions taken elsewhere. It needs to be underlined here then that participation is prompted only by ownership of the resource too. This ownership needs to be grounded in the people's right to water and ownership of the local structures for harvesting water, along with the resource.

With that being said, the argument for decentralization should begin perhaps with a bit of history. Prior to the British Colonization and a near total revamping of the administrative and governance structures, India had a rich history of decentralized water management. Being a tropical country that receives seasonal rainfall the surface and groundwater reserves of India were not replenished throughout the year, but in a periodical and limited manner. This then prompted communities to devise strategies at conservation and management (Agarwal \& Narain, 1997). Rainwater harvesting was actively practiced in India as a mode of societal adoption to the environmental and natural conditions of India. Communities owned and managed wells, tanks and ponds which stored rainwater and in turn replenished the groundwater. Community ownership and management of water resources - in contrast to individual or highly state centered approaches prevailed and a strong association of culture and spirituality with water determined the usage and management of the resource. This prevented its crass commercialization while not excluding the economic transactions that were related to it. A complex system of customary rights, often grounded in religion, and which was suitable for the needs of each community was evolved and followed to determine the user's rights over water and water resources (Vani, 2002). With custom having authority as an independent source of law, local governance of natural resources was also de jure. The role of the State in this realm was an administrative one and not legislative - thus not precluding local law making that suited the needs of 
a community, in consonance with the local conditions (Vani, 2002). The result of such decentralized law making was that the rights to resources were defined, allocated and regulated as a part of the local management framework. This integration of the functions of defining, allotting and regulating rights with local management also lead to the creation of and allocation of duties as well - which in turn played an important role in conservation of the resource by the community. However, the Colonial establishment brought down this system which was a creation of centuries of collective experience. In place of a decentralized and community driven approach, the Colonial power established highly centralized system of governance, aimed solely at maximization of collection of revenue and increasing its profits (Agarwal \& Narain, 1997). The post-colonial governments merely continued with the colonial systems and approaches and nothing was done to revive the indigenous approaches to management.

The allure to history was only to show that decentralized management is not a novel concept in India and to decentralize is in fact only to rebuild what was demolished by the Colonial enterprise. However, this is not to say that it is easy start rebuilding. As it was stated before, deciding on the manner of decentralization and the entity to be used for this is indeed the moot question. There are two approaches that can be adopted: One to build fresh institutions for decentralized water governance - such as Water Users Associations (WUAs) and integrate them into the existing central authorities. Another option is to divulge these powers on the existing constitutionally aspired and mandate structures for decentralized governance - the Panchayats. Which of these is to be preferred is the next question in line.

The WUA model for decentralization has already been tried in India, in a different context though - that of irrigation. The model was implemented in Participatory Irrigation Management (PIM) programs in many States in India seeking to empower Farmers Organizations as WUAs (Upadhyay, 2009a). WUAs in this context were legally backed institutional foundations for PIM all across the country (Joshi, 2000). The approach adopted was to form WUA with participating farmers who drew water from a common resource. However, the striking aspect of this PIM program was the scant attention that was given to ownership rights over these resources. Thus, while the WUAs were legally bound to deliver water to its members, the government's rights over water and water resources remained unchallenged (Upadhyay, 2009a). While the PIMs were efficient in delivering water where it was available in plenty, there was no drive or incentive for them to adopt strategies for the conservation or sustainable management of the resource as the resource itself did not belong to them .The government could divert the waters in the resource, if it deemed that to be appropriate. The experience with this was also similar in China where the collectives failed to take steps to conserve groundwater resources as reduction in pumping from any tube well only made more water available to others (Kramer, 1989). Some of the States did have legislations that established a right of the WUAs to receive a certain bulk quantity of water. However, even these legislations and the Rules framed under them did not state clearly what remedies were available to the WUAs if this right was not honored. Most important of all, the difficulties lay in integrating the working of these bodies with the other departments of the State Governments (Vani, 2009). Essentially these attempts were only in the nature of dealing with the question of management of the delivery systems and in its essence no powers for planning or resource management were delegated (Mosse, 
2003). Further, the models of WUAs adopted paid attention only to surface waters and not to groundwater irrigation - when the bulk of Indian agriculture is heavily dependent on that resource. Further, establishing fresh WUAs involves considerable investment and energy in building fresh institutions, ensuring participation of all persons involved in these institutions and most of all incurs fresh financial commitments. Educating the population of the importance of these structures and expecting them to find time for such participation are also other challenges that stand in our way.

The other approach would be to make use of the existing infrastructure for decentralization envisaged by the Constition - the Panchayati Raj system. The Panchayat Raj system was the product of the $73^{\text {rd }}$ and $74^{\text {th }}$ Constitutional Amendments of India, which was the first attempt at decentralization of governance in India. For Rural areas, the $73^{\text {rd }}$ Amendment mandated the formation of a three tier Panchayat system in every state whose members are directly elected by the public. However, it needs to be noted that there are no mandatory provisions for the devolution of powers on the Panchayats. Article 243G leaves it to the discretion of the States to decide what is the extent of the powers to be devolved on a Panchayat within its jurisdiction. The Eleventh Schedule to the Indian Constitution contains a list of 29 subject matters and powers with respect to the "implementation of Schemes" and "preparation of plans for economic development and social justice" may be entrusted to the Panchayats. Of the 29 matters elaborated in the Eleventh Schedule, as many as 14 are relevant for natural resource management, with implications for water resources. Different states have adopted different extent of decentralization of power pursuant to the $73^{\text {rd }}$ Amendment (GOI, 2004). While some of the States have moved ahead in decentralization of planning power and natural resource management, most of them have lagged behind (World Bank, 2000). To make a survey of the extent of decentralization and the different results is in itself a huge task and lies beyond the scope of this paper. However, one of the most successful cases of decentralization - that of Kerala will be taken up to show how resource ownership being vested in the Panchayat changes the approach of people towards resource conservation and better management.

The Legislature of Kerala was one of the first legislatures to enact a comprehensive law for devolution of powers to the Panchayats in the year 1994. Both the Constitution and the Panchayat Raj Act of Kerala recognize the jurisdiction of the Panchayat over water resources. The subjects "minor irrigation, water management and watershed development" and "drinking water" have been included in the Schedule of powers and functions of the Panchayat in the Constitution of India by virtue of Art. 245G read with the Eleventh Schedule, Entries 3 and 11 of Constitution of Indi. The Kerala Panchayat Raj Act of 1994 provides that all 'public water courses' and a set of other enumerated water resources shall be considered as "transferred and absolutely" vested in the Panchayat (S.218, Kerala Panchayat Raj Act.). This can then translate to mean that the Panchayat owns and has power to control the use of drinking water resources (other than those which are privately owned, such as wells, lakes and ponds on private lands) within its jurisdiction. It can on the one hand indeed be argued that by virtue of this provision, the groundwater resource, which is an important drinking water source for the Panchayat, already vests in the Panchayat. However, this argument was not accepted by the Division Bench of High Court of 
Keala in the Coca Cola Case. This judgment is currently under appeal before the Supreme Court and a final decision is awaited.

However, what interests us at present is not the technical argument involved but the results that this provision has produced. Decentralised planning and management of water resources is found to be a success story in several parts of Kerala. Decentralization initiatives after the $73^{\text {rd }}$ and $74^{\text {th }}$ Amendments gained a fresh life after the Panchayat and Municipalities Act of 1994 gave the Local Self Government Institutions (LSGIs) more power for planning and resource allocation. Planning was thus decentralised with the "janakeeyasoothranam" (which literally means decentralized and people's planning initiatives) programme and resource ownership and management was transferred to the LSGIs, which then induced more community participation in management. To cite an example, artificial water ponds in Trichur, a small town in Kerala, that were neglected for years by the administration and filled with filth and dirt at once received maintenance attention, as the people living around the pond and those who depended on it for drawing water came together and demanded its repair. The pressure exerted by the people by the counsellors translated into the district administration working with other departments for repair and maintenance of the water body (The Hindu, 2006; The Hindu, 2007). The success story of communities coming together to repair old water bodies and use them once the authority vested in the Panchayat has been repeated in different parts of Kerala.

The ownership of a resource makes an immediate incentive for the people and the administration alike to act. This in turn drives sustainable management and an approach for conservation of the resource. Without this key element of resource ownership, efforts at conservation and judicious use are not aims that drive community action. The Model Bill for groundwater regulation identifies rainwater harvesting and community action for the same as the means and methods to replenish the groundwater resource (Section 19, Model Bill). However, without this key element of resource ownership, communities lack the incentive to act as to create and conserve a resource that they don't own and that could be taken away by an act of the State will not be sympathetically considered.

Section 218 of the Kerala Panchayat Raj Act is indeed a step forward in that it vests the ownership of the resource on the community that uses and maintains it. It can well be argued that groundwater also falls within the capture of the provision, however clarity in explicit would be better that inferences from the text. A complete approach towards decentralization would thus be to explicitly include groundwater too within the purview of this provision.

This is not to say for a moment that the task ends with such vesting and that solutions appear on the horizon just with this. Undoubtedly there are difficulties associated with this process - aquifers will have to be delineated, rules and procedures to ensure equity will have to be formed (particularly in a cast ridden society like India) and gender concerns will have to be addressed. The State will continue to have a role to play in this exercise. Ramaswamy Iyer has pointed out that this kind of management has already in operation in the Joint Forest Management Programme as also in the participatory watershed development programmes and that with sufficient modifications they can be extended to groundwater as well (Iyer, 2003). Apart from this challenges remain in ensuring that decentralization would truly evoke participation and 
representation of all interests. It is one thing to say that the power to make decisions is decentralised and another that the decisions are made in a participatory manner. The manner in which the Panchayats have been working is still far from satisfactory and processes to ensure larger participation and functioning of the gram sabhas will have to be set in motion. Clearly, the paybacks of this proposed system is bound to take time and will be produced only with investments of efforts into the same. However, that there are difficulties in the approach is no reason to reject this, as the advantages gained outweigh the difficulties.

\section{DISCUSSION AND CONCLUSION}

With the growing demand for soft drinks and bottled water, it can be expected that Multinational Companies (MNCs) that produce and market these products would attempt to further expand their manufacturing activities. Since these companies depend on groundwater for their manufacturing process, the importance of appropriate regulation of the resource is of immediate contemporary significance.

The present approach of Indian law towards groundwater is based on the archaic English Common Law approach of tying it with ownership of land and this is no longer suitable for the needs of the present times. The massive scale of extraction such as the one that happened in Plachimada and is happening in other parts of India is made possible because of this legal framework. In India, up to $90 \%$ of the rural population depends on groundwater for both drinking water and irrigation needs. Allowing MNCs to extract the groundwater and run the water table dry would infringe the rural population's right to water, food and occupational security. Further, typing up groundwater with ownership of land creates exclusionary regimes as only those who own land would have access to the resource. Bundling the ownership of groundwater with that of land thus does not serve considerations of equity and or sustainable use of the resource. Even if a person can prove the link between these massive extractions and its impact on groundwater, law grants him no remedies as the extractor is only exercising rights incidental to ownership over his own property.

Attempts to reform groundwater law in India have also only been partial ones and have not touched this central question of ownership over the resource. The Model Bill floated by the Central Government and the existing State legislations do nothing more than employ a permit system and create centralized structures of governance. The permit systems themselves are silent about quantitative restrictions that may be placed and the grounds on which permits can be rejected. Though some of the legislations mention public interest to be a consideration while granting permits, the expression itself can be too flexible and can be interpreted to give preference to investments and foreign exchange rather than rural - agricultural water needs. Most important of all, these legislations have no provisions for seeking public opinion or ensuring public participation while making a decision on whether or not to grant a permit. The latest revision of the Model Bill attempts to bring the concept of public trust over water resources. However, the application of Public Trust over groundwater is problematic as firstly, it makes it capable of ownership by no one and secondly, it is doubtful whether any form of extraction of the resource would be possible as public trust renders a resource as not appropriatable by any one. Further, Public Trust only helps to reinforce the powers of State and the response of the State to Plachimada and 
Placbimada like situations are not ones that inspires much confidence. The Rule seems to be that the MNCs are favoured and over the villagers.

An examination of the Water laws of Countries with large geographical areas and diverse population reveals two things: Firstly that the law makes groundwater the property of the State and only a user right is granted to individuals or entities (with quantitative restrictions). Secondly, there are also strong provisions in the law to ensure public participation and consideration of the opinion of the public while such users rights are granted. Further, the evolving norm in such situations is also to decentralize water governance to ensure that decisions are made at the place where its effects are felt. The Indian law has failed completely in addressing these concerns.

Groundwater governance in India thus needs a change in its approach from its current tendancy to concentrate decision making power in the hands of the State or Central Governments to a decentralized one that ensures space for public participation in the decision making processes. In tune with the constitutionally mandated program of action for decentralization, decentralization of water governance should also centre on the Panchayats. However, it is not just enough to grant the Panchayats mere administrative powers over groundwater regulation. Real decentralization should also include ownership over the resource as only then would there be the incentive to protect it and use it in a sustainable fashion. Without this, programs of actions for groundwater sustenance such as rain water harvesting would only draw flak as a population finds no incentive in protecting a resource that can be taken away from them, without their permission. 


\section{REFERENCES}

Agarwal A. \& Narain S. 1997. Dying Wisdom: Rise, Fall and Potential of India's Traditional Water Harvesting Systems. Centre for Science and Environment: New Delhi. 404 p.

Aiyer A. 2007. Allure of the Transnational: Notes on Some Aspects of the Political Economy of Water In India. Cultrual Anthropology. 22: 640 -658.

Background Note. 2011. Background and rationale to the Draft Model Bill for the Conservation Protection and Regulation of Groundwater. The Planning Commission of India: New Delhi. 12 p.

Baxi U. 2005. Colonial Nature of the Indian Legal System. In: Sociology of Law, Deva I. (ed.) Oxford University Press: New Delhi. 376 p.

Bijoy CR. 2006. Kerala's Plachimada Struggle: A Narrative on Water and Governance Rights. Economic and Political Weekly. 41: 4332-4339.

Blumm M. 1989. Public Property and the Democratization of Western Water Law: A Modern View of the Public Trust Doctrine. Environmental Law. 19: 573- 604

Broom H. 2010. A Selection of Legal Maxims: Classified and Illustrated. Maxwell: New Delhi. 993 p.

Clark SD. 1999. Reforming South Africa Water Legislation Australian Examples. In: Issues in Water Law Reform, FAO Legislative Studies. 67: 1-22.

Cullet P. 2012. The Groundwater Model Bill: Rethinking Regulation for the Primary Source of Water. Economic and Political Weekly. 45 (47): 40 -47.

Dublin Statement on Water and Sustainable Development. 1992. International Conference on Water and the Environment Development Issues for the $21^{\text {st }}$ Century, Dublin.

Frank RM. 2012. The Public Trust Doctrine: Assessing its Recent Past \& Charting its Future. U.C. Davis law Review. 45: 665- 691.

Frederiksen HD, Berkoff J, Barber W. 1993. Water Resources Management in Asia, Vol. 1, World Bank Technical Paper No. 212. The World Bank: Washington D. C. 188 p.

Getzla J. 2004. A History Of Water Rights At Common Law, Oxford University Press: Oxford. 398 p.

GOI. 2004. Government of India, Annual Report of the Ministry of Rural Development 2002-2003. Government of India: New Delhi. 34 p.

Gorriz M, Subramanian A, Simas J. 1999. Irrigation Management Transfer in Mexico: Process and Progress. World Bank Technical Paper No. 292. The World Bank: Washington D.C. 136 p.

Hoering U. 2008.W ater to the People - Drinking Water and Water for Livelihoods: Conflicts and Alternate concepts in India. Centre for World Solidarity: Secunderabad. 99 p. 
Iyer RR. 2003. Water: Perspectives, Issues Concerns. Sage Law Publications: New Delhi. 368 p.

Jaspers FG. 2003. Institutional Arrangements for Integrated River Basin Management. Water Policy. 5: 77-90.

Joshi HR. 2000. Participatory Irrigation Management: New Paradigms for the 21 ${ }^{\text {st }}$ Century. Rawat Publications: New Delhi. 699 p.

Koonan, S. 2007. Legal Implications of Plachimada : A Case Study. International Environmental Law Research Centre Working Paper 2007-05. International Environmental Law Research Centre: Geneva. 20 p.

Kramer R. 1989. Groundwater Management in China. In: Workshop on Efficiency and Equity in Groundwater Use and Management. Institute of Rural Management: Anand. 21-35.

Kux D. 1993. India and the United States: Estranged Democracies, 19411991, National Defense University Press Publications: Washington. 514 p.

Kysar DA. 2005. Sustainable Development and Private Global Governance. Texas Law Review. 83: 2109 -2166.

Lailos J, Tomar D. 1992. Energy and Natural Resources Law In A Nutshell. West Publishing Co. : Minessotta. 554 p.

Malone LA. 1990. The Necessary Interrelationship Between Land Use and Preservation of Groundwater Resources. UCLA Journal of Environmental Law \& Policy. 9: 1-72.

Moench M. 1992. Chasing the Water Table: Equity and Sustainability in Groundwater Management. Economic and Political Weekly. 27 (51/52): 171-177.

Mosse D. 2003. The Rule of Water: Statecraft, Ecology and Collective Action in South Asia. Oxford University Press: New Delhi. $337 \mathrm{p}$.

Mostert E. 2004. The Challenge of Public Participation. Water Policy. 5: $179-197$.

Phansakar S, Kher V. 2006. A Decade of Maharashtra Groundwater Legislation: Analysis of the Implementation Process. Law Environment \& Development Journal. 2 (1): 69-79.

Planning Commission. 2007. Report of the Expert Group on Groundwater Management and Ownership. Government of India : New Delhi. 70 p.

Priscoli JD. 2004. What is Public Participation in Water Resources Management and Why Is it Important?. Water International. 29 (2): $221-227$.

Rao VS. 1996. Law Relating to Water Rights. Asia Law House: Hyderabad. $302 \mathrm{p}$.

Rasband J, Salman J, Squillace M. 2004. Natural Resources Law and Policy. Foundation Press: New York. 1277 p.

Reichert G. 2005. The European Community's Water Framework Directive : A Regional Approach to the Protection and Management of Transboundary Freshwater Resources? In: Water Resources and International Law, Boisson de Chazournes L 
\& Salman MAS. (eds.). Martinus Nijhoff Publishers: Leiden. $848 \mathrm{p}$.

Rio Declaration on Environment and Development. 1992. The United Nations Conference on Environment and Development, Rio de Janeiro.

Rogers P, Bhatia R, Huber A. 1998. Water as a Social and Economic Good: How to Put the Principle into Practice, Global Water Partnership. Technical Advisory Committee Background Papers No.2. Global Water Parternship/Swedish International Development Cooperation Agency: Stockholm. 40 p.

Salman MAS, Bradlaw D. 2006. Regulatory Frameworks for Water Resources Management : A Comparative Study, The World Bank: Washington D. C. 218 p.

Sax JL. 1970. The Public Trust Doctrine in Natural Resource Law: Effective Judicial Intervention. Michigan Law Review. 68 (3): $471-566$.

Singh C. 1991. Water Rights and Principles of Water Resource Management. Indian Law Institute: New Delhi. 160 p.

Singh C. 1992. Water Rights in India. Indian Law Institute: New Delhi. 389 p.

Stein R. 2000. South Africa's New Democratic Water Legislation: National Government's Role as a Public Trustee in Dam Building and Management Activities. Journal of Energy and Natural Resources Law. 18: 284

Stevens JS. 1980. The Public trust: A Sovereigns Ancient Prerogative becomes the People's Environmental Right. U.C. Davis law Review. 14: 195- 232.

Swamy RN. 2011. Water Insecurity: The Plachimada Struggle. Economic and Political Weekly. 52 (1): 26-33.

Swenson E. 1998. Public Trust Doctrine and Groundwater Rights. University of Miami Law Review. 53: 363 -391.

Tarlock AD, Corbridge JJ Jr, Getches DH. 2002. Water Resources Management: A Casebook on law and Public Policy (5th Editon.). Foundation Press: New York. 930 p.

Tortajada C. 1999. Legal and Regulatory Regime for Water Management in Mexico and its Possible use in Other Latin American Countries. Water International. 24(4): 316-322.

Trelease FJ. 1974. Water Law: Resource Use and Environmental Protection. American Case Book Series. West Publishing Co: Minnesota. 1250 p.

Upadhyay V. 2009. Water Law and the Poor. In: Legal Grounds: Natural Resources Identity and Law in Jharkand. Sundar N. (ed.). Oxford University Press: New Delhi. 132-156.

Upadhyay V. 2009a. The Ownership of Water In Indian Laws In: $W$ ater and the Laws in India, Iyer RR. (ed.). Sage Law: New Delhi. 135-158. 
Vani MS. 2002. Customary Law and Modern Governance of Natural Resources in India - Conflicts, Prospects for accord and Strategies, In: Legal Pluralism and Unofficial Law in Social, Economic and Political Development, Pradhan R. (ed.) Papers of the XIIIth International Congress April, ICNEC: Commission On Folk Law and Legal Pluralism.

Vani MS. 2009. Community Engagement in Water Governance, In: Water and the Laws in India, Iyer RR. (ed.) Sage Law: New Delhi. 125- 157

Velasco HG.1999. Modernization of Water Legsilation : The Mexican Experience, In : Issues in Water Law Reform. FAO Legislative Studies. 67: 83- 106.

Villareal FG, Valesco HG. 1994. Water Resources Management and Planning in Mexico. International Journal of Water Resources Development. 10: 239-255.

Wilkinson C.F. 1989. The Headwaters of the Public Trust: Some Thoughts on the Source of the Traditional Doctrine. Environmental Law 19: 425- 472.

World Bank.1993. Water Resources Management - A World Bank Policy Paper. The World Bank: Washington D. C. 140 p.

World Bank. 2000. Overview of Rural Decentralization In India. Vol. 1. The World Bank: Washington D.C.

World Bank. 2002. China: Agenda For Water Sector Strategy For North China, World Bank Report 22040-CHA . Vol.1. The World Bank: Washington D. C. 159 p.

\section{CASES}

Acton's Case. 1843. Judgment in Acton v. Blundell, 12 M. \& W. 324, URL: http://ufdc.ufl.edu/WL00004438/00001, Accessed on 23 March 2013.

Bradford's Case. 1895. Judgment in Bradford v. Pickles (1895) A.C. 587 H.L, URL: http://www.uniset.ca/other/cs5/1895AC587.html, Accessed on 23 March 2013.

Coca Cola Case. 2002. Judgement of the High Court of Kerala in Hindustan Coco-Cola Beverages Pvt. Ltd. v. The Supdt. Of Police, Palakkad in Original Petition No., 11598/2002, dated. 04 June 2002.

Coca Cola Case. 2003. Judgement of the High Court of Kerala in Perumatty Grama Panchayat vs State Of Kerala, dated 16 December 2003, URL: http://www.indiankanoon.org/doc/1161084/, Accessed on 17 March 2013.

Coca Cola Case. 2005a. Judgement of the High Court of Kerala in Hindustan Coco-Cola Beverages Pvt. Ltd v. Perumatty Grama Panchayat, 2005 (3) KLT 10, URL: http://www.indiankanoon.org/doc/837363/, Accessed on 28 February 2013 
Coca Cola Case. 2005b. Special Leave Petition (Civil) No. 25046/2005, Perumatty Grama Panchayate Ors. v. Hindustan CocoCola Beverages Pvt. Ltd., Before the Supreme Court of India.

Frazier's Case. 1861. Judgment of the Supreme Court of Ohio in Frazier v. Brown, 12 Ohio St. 294 (1861).

Higday's Case.1971. Judgment in Higday v. Nickolaus, 469 S.W. 2d 859 (1971).

Intellecuals Forum Case. 2006. Judgment in Intellectuals Forum v. State of A. P., (2006) 3 SCC 549.

Kesava Bhatta v. Krishna Bhatta, AIR 1946 Mad. 334.

M.C.Mebta v. Kamal Nath And Others, (1997)1 SCC 388

M.I Builders Case. 1999. Judgment in M.I. Builders v. Radhey Shyam Sabu, (1999) 6 SCC 464

Michel's Case. 1903. Judgement in State v. Michels Pipeline Constr. Inc., 217 N.W. 2d 339 (Wis. 1903)

Nassauskiebung Case, 1981. Decision of July 15,1981, as discussed in Yan Zhu, Klaus-Dieter Balke.2008. Groundwater Protection : What We can Learn from Germany, Jounral of Zhejiang University Science \& Business. 9(3): 227-231.

Pasadena Case. 1949. Judgment in City of Pasadena v. City of Alhambra, 207 P.2d 17 (Cal. 1949).

Rambabu Case, 2002. Judgment of the High Court of Andhra Pradesh in Madia Reddy Padma Rambabu v. The District Forest Officer. 2002 (3) ALT 57.

Reliance Case. 2010. Judgment of the Supreme Court of India in Reliance Natural Resources Ltd. v. Reliance Industries Ltd , (2010) 7 SCC 1.

The 2G Spectrum Case. 2012. Judgment of the Supreme Court of India in Centre For P.I.L. \& Ors. vs Union Of India \& Ors., Judgment dated 2 February, URL:

http://www.indiankanoon.org/doc/116116642/, Accessed on 30 march 2013.

Waiahole Ditch. 2000. Judgment of the Supreme Court of Hawaii in In re Water Use Permit Applications for the Waiahole Ditch, 9 P.3d 409 (Haw. 2000).

\section{OTHER REFERENCES}

BBC. 2003. Coca-Cola's 'toxic' Indian Fertilizer. The BBC News (24 July).

Business Line. 2006. Pepsi Bottling Plant in Virag Told Not to Use Groundwater (March 10)

Cockburn A. 2005. Message in a Bottle: How Coca-Cola Gave Back to Plachimada. Counterpunch (April 16), URL: http://www.counte rpunch.org/cockburn04162005.html, Accessed on Mar. 12013

CPCB. 2005. Groundwater. Central Pollution Control Board, Government of India Ministry of Environment \& Forests, 
URL: http://www.cpcb.nic.in/groundwater/chl50703.htm.> Accessed on 12 March 2013.

Economic Times. 2012. Delhi Groundwater may Run dry in 3-5 years: Study (December 19).

Hazards Centre.2006. Ground Water Resources In Plachimada: Coca Cola Stores Toxics For Future Generations. Hazards Centre \& People's Science Institute: New Delhi \& Dehradun, URL: http://www.indiaresource.org/documents/PlachimadaReport WaterPollution.pdf, Accessed on 04 March 2013

HPC. 2010. Report And Recommendations Of The High Power Committee On The Extent Of Damages Caused By The Coca Cola Plant At Plachimada, Palakekad District, URL:

www.indiaenvironmentportal.org.in/files/coca-cola-kerala.doc, Accesed on 28 February 2013.

India Resource Center. 2013. Mehdiganj - The Issues. India Resource Center News Release (March7), URL:

http://www.indiaresource.org/campaigns/coke/2013/mehdiga njfact.html, Accessed on 11 March 2013.

India Resource Centre. 2011. Coca-Cola Extracts Groundwater Even as Farmers and Community Left Without Water. India Resource Center News Release (September 21). URL:

http://www.indiaresource.org/news/2011/1008.html, Accessed on 11 March 2013.

India Today. 2012. 162 Illegal Borewells Discovered In Gurgaon, (August 21)

Misra, S.S. 2013. Act To Make Coca-Cola Pay, Down to Earth ( 31 March

NUS Services Limited. 2004. Accusations of Water Shortages and Negative Environmental Impacts Caused by Nine Bottling Operations/Factories Used in the Manufacture of Coca-Cola Products in India, URL: http://www.iuf.org/cocacola/archives/NUSSL $\% 20$ Coca-Cola $\% 20$ in $\% 20$ India $\% 20$ \%20update\%20briefing.pdf, Accessed on 1 March 2013.

Rajeev D. 2005. India: Everything Gets Worse With Coca-Cola, Common Dreams.org Newscenter (Aug. 22), URL: http:// www.commondreams.org/headlines05/0822-01.htm, Accessed on 27 February 2013.

Sen A. 2003. Heat on Cold Drinks, the Statesmen (19 August).

Shiva V. 2005. India: Soft Drinks, Hard Cases, Environment \& Poverty Times. 4(89): 6-9.

The Guradian. 2004. Things Grow Better with Coke (2 November)

The Hindu. 2004a. Water Board Disputes Coca-Cola's Claim on Ground Water (June 17)

The Hindu. 2004b. Marchers Against Coca-Cola Court Arrest (September 29)

The Hindu. 2006.Vadakeechira Beautification Project to be over by Onam (July 28)

The Hindu. 2007. New Life for Historical Pond in Trichur (July 9) 
Viswanathan S. 2003. Communities Protest Coca-Cola in Tamil Nadu, The Frontline (June 20).

Viswanathan S. 2005. Bottling Thamiraparani. The Frontline (October 8).

Wyrwoll, Paul. 2012. India's Groundwater Crisis, Australian National University Discussion Paper 1228 (July), URL:

http://environmentportal.in/files/file/India's $\% 20$ groundwater \%20crisis.pdf, Accessed on 01 March 2012 